\author{
Ph.D., Associate Professor Yuliya Konoplina \\ Ukrainian Academy of Banking of the National Bank of Ukraine, Ukraine
}

\title{
The potential of Ukrainian social insurance system improving
}

In our opinion there are significant reserves to improve the effectiveness of obligatory state social insurance system functioning videlicet: to analyze state social insurance system as specific sphere of economic relations which originates from insurance, has very close connection with insurance, but at the same time differs from insurance considerably. Social insurance appeared as a result of insufficiency of private-business insurance and the necessity of state interference in order to overcome the market failures, which are typical for private-business insurance. The problems of social justice and income adequacy are especially actual in modern society. The problems of social justice and income adequacy very often become sharper exactly as the consequence of some social risks instance. Citizens' protection against negative consequences of such risks instance becomes the one of the modern state top priority tasks. At the same time the socially oriented state needs more financial resources for social problems solving. Moreover, such state needs precise regulation of all the financial aspects, which ensure state social security commitments to citizens. That's why the importance of public and financial effectiveness of state social insurance system becomes more and more advanced. Taking all the abovementioned into consideration it is necessary to underline that the study of social insurance system effectiveness and the role of social risks and insurance principles in frames of social insurance is especially actual.

In modern science literature we can often come across the discussions on the problem of improving the efficiency of Ukrainian social insurance system functioning. As the method of solving this problem in some publications we can meet the propositions to shift from social insurance contributions towards social insurance taxes, and to set the new basis for calculation of social insurance tax on behalf of 
employers, namely not the wages fund but sales proceeds. But in our opinion, such method of solving the problem mentioned is not acceptable.

Indeed, exactly wages fund is determined as the basis for calculation of social insurance contributions on behalf of employers, and such state of affairs is absolutely reasonable but simultaneously contains some factors that negatively influence the effectiveness of social insurance system. The specific character of the mentioned basis for calculation of social insurance contributions lies in following: employers have the significant motivation to suppress wages growth and to use illegal ways of labour remuneration. It should be noted that the general economic situation in Ukraine is characterized by negative trends in sphere of labour remuneration. In conditions of insufficient opportunity to get a job and low average wage level the significant part of economically active citizens of Ukraine work abroad. In Ukraine high rates of employment growth are observed only concerning people at the age of less than 20 years old or more than able-bodied age. This situation is conditioned by growing demand for low qualified labour force. Such state of affairs demonstrates the regressive trends in national economy as a whole, because developed countries are characterized by opposite tendencies, i.e. by the growing demand for high qualified labour force. In addition, the share of wages in the structure of GDP and production cost value still remains low and inadequate to worldwide experience. This situation is connected with employers' pursuit to win in price competition, i.e. decrease prices by means of saving on wages level.

Taking into consideration all the above mentioned, illegal ways of labour remuneration will be still wide spread even under the change of basis for calculation of social insurance contributions on behalf of employers (from wages fund towards sales proceeds), because such situation is conditioned by economic reasons of largescale and deep character. Such statement may be proved by the experience of Russian Federation, where consummation of single social tax was provided on the basis of regressive taxation scale in order to stimulate employers' refusal from using illegal ways of labour remuneration. But the aim set was not achieved, and as the 
consequence of insufficient receipts social insurance system suffered from significant deficiency.

With respect to the shift from social insurance contributions towards social insurance taxes it should be noted that such shift is not acceptable, because such shift fully contradicts insurance principles use in frames of obligatory state social insurance. The categories "social tax" and "social contribution" differ from each other with regard to such parameters as social-economic nature and role in social protection system. Taxes may be characterized as non-repayable payments, and social contributions correspond the form of wage reserving in order to ensure payments in the case of the insured risks instance (illness, industrial diseases and industrial injuries, unemployment, old age) and may be repayable in the form of insurance disbursement. In compliance with social insurance legislation it is prohibited to include social insurance contributions into state budget as well as it is prohibited to use social insurance contributions for the purposes not set in this legislation. The shift from social insurance contributions towards social taxes may lead to growth of state budget expenses necessary to support financial stability of social insurance funds. Such state of affairs may lead to transformation of social insurance system into social assistance system.

To date the significant potential of Ukrainian social insurance system improving consists of excluding from social insurance system frames insured persons entitled to special benefits. It is necessary to underline that the necessity to make payments for such insured persons destabilizes and unbalances obligatory state social insurance system. Payments for such insured persons should be made from the sources other than social insurance system. For example, people who have harmful conditions working record are pensioned off earlier than other groups of employees and their pensions should be paid from corporate or professional pension funds. But it is necessary to underline that shift of such financial burden from the social insurance system onto corporate pension funds may be implemented only in long-term perspective, gradually and without violence of mentioned groups social rights. 